\title{
The Vimalakirtinirdeśa's Narration on the Amrta Distribution and its Exploitation by the Pusa chutai jing's Authors
}

\section{Elsa LEGITTIMO}

\section{Introductory notes}

The present paper discusses the means employed by the authors of the Pusa chutai jing for conferring an altered message regarding events and motives that occur in the Vimalakirtinirdeśa. It further includes a comparative study on the așta-vimokșa concept in relation to food or drink.

Whereas the Vimalakirtinirdeśa, the key topic of this year's Congress of the Japanese Association of Indian and Buddhist Studies, is still at the crest of its fame, the Pusa chutai jing (The Sutra held by the bodhisattva within the womb 菩薩處胎經) ${ }^{1)}$ belongs to a once influential and now forgotten genre of Buddhist literature. ${ }^{2)}$ Just before entering nirvāna the Buddha recalls in this sūtra the very first exposition he held in his mother's womb and creates a great womb palace for his auditors. A certain parallelism exists with Vimalakïrti's empty house or sick-room that accommodates a huge assembly.

\section{The Tathāgata's food gift and the creation of golden-colored bodhisattva(s)}

The Vimalakirtinirdeśa's chapter nine, the "Nirmitabhojanānayanaparivarta" ("The chapter on the created/fictive food's provision"), ${ }^{3)}$ focuses on the amrta (sweet dew 甘露) given by Sugandhakūta Tathāgata to the golden-colored fictive bodhisattva sent to the Sarvagandhasugandhā universe by Vimalakïrti. The main heroes of this play are Vimalakirti, his fictive bodhisattva who brings back the precious food, and Sugandhakūta Tathāgata. The amrta is distributed to the beings of this world without Śākyamuni Buddha's personal intervention.

Chapter four ("The Buddha tree" 佛樹) of the Pusa chutai jing relates to these events in its final section on the special powers ( $r d d h i-p a \bar{d} a$ 神足) the Buddha acquired as a bodhisattva: 1) eye (divya-cakșus), 2) ear (divya-śrotram), 3) nose ${ }^{4)}$, 
4) mouth, ${ }^{5)}$ and 5) bodily power. Between the third and fourth power exists an apparent chapter closing: Twelve yojanas of living beings become awakened and ask to be reborn in the Gandhasugandhā buddhaksetra (香積佛刹). ${ }^{6}$ ) Under the "mouth power" the text then states:

From Jambudvīpa up to the eighteenth heaven, everybody sees the Tathāgata eating. The bodhisattvas of the first stage up to the forth stage perceive the Tathāgata's body's lapis lazuli throat. The bodhisattvas of the non-returning (avaivartika/anāgāmin 不退轉) stage up to the ninth stage perceive the strong and the ailing ones. The heavenly beings pick up the Tathāgata's food, give it to all the other worlds, and there carry out buddha-activities (buddha-kārya 佛事). This is the retribution of the Tathāgata's mouth power. The Tathāgata shows the food's taste, the taste of tastes (rasarasāgratā 次第味味), ${ }^{7)}$ the unmovable taste that is neither swallowed nor chewed. While lifting up the food towards his mouth the Tathăgata concentrates his mind on thinking that the sentient beings of the five destinies in the ten directions, and all the other beings, shall likewise experience this taste. When he thinks of them they all become full and satisfied. Like monks reaching the ninth dhyana stage whose minds are soft, beautiful and satiated. This is the bodhisattva mahāsattva's pure and calm mouth power." ${ }^{8)}$

Another relevant passage is found in the sūtra's chapter eleven ("Felicity" anumodanā 隨喜). The Buddha has a golden body (金體) and holds an exposition for Uṣnịṣa-rāja (頂王) bodhisattva of the “Safe dwelling world” (安住世界):

By his divine powers the Buddha then transforms the trisāhasra-mahāsāhasra lokadhātu (one-billion-worlds) into shiny golden color. He makes those in the meeting see the world of joy where the bodhisattvas are sitting on seven-treasure lotus flowers. Their disciples and retinue are all in golden color. They feed on meditation (dhyāna) and release [and take it] as their food and drinks. ${ }^{9}$

The Pusa chutai jing's authors took over several themes and narrations from the Vimalakirtinirdeśa. But they eclipsed the principal "heroes" and Śākyamuni Buddha is the sole "hero" responsible for the creation of golden-colored bodhisattvas. His food, respectively the satiating taste of it, is telepathically distributed from Jambudvipa to the beings of all the other worlds.

\section{An analysis of the așta-vimokșa concept in relation to food or drink}

Within the Chinese Canon the concept of the eight-fold liberation (așta-vimokșa八解 
The Vimalakirtinirdeśa's Narration on the Amrta Distribution and its Exploitation by the Pusa chutai jing's Authors (E. LEGITTIMo)

脫) is seen in simile-like relation with: the eight-fold path, meditation, nirvāna, the six abhijñ $\bar{a}$ powers, water of release, a pond, or something eatable or drinkable. This last combination is of significance for the topic of this paper. The few scriptures containing this theme can be classified into two categories: 1) the three versions of the Vimalakirtinirdeśa ${ }^{10)}$ and three Vimalakirtinirdeśa commentaries, $\left.{ }^{11}\right)$ and 2) three texts translated by Zhu Fonian.

The simile like picture of the asta-vimokṣa concept in relation to food appears twice in the Vimalakirtinirdeśa: in chapter three ("Śrāvakabodhisattvavisarjanapraśna", "The śrāvakas' and bodhisattvas' refusal to question [Vimalakīrti]") and in chapter nine.

In chapter three the Buddha tells his worthy disciples to make a visit to Vimalakirti and to inquire about his health. One after the other, they refuse with reference to their past encounters and discussions with the virtuous man. Even Kāśyapa refuses and explains that Vimalakīrti had once criticized him:

Honorable Mahākāśyapa, if you can without overstepping the eight depravities concentrate on the eight liberations, if through the equality of the depravities you penetrate the equality of holiness, and if by this single rice ball, you are able to satisfy all the beings and to make offerings to all the Buddhas and all the holy beings, only then you should eat yourself. The one who eats in this way is neither soiled nor non-soiled, neither concentrated, nor out of concentration, neither in transmigration, nor fixed in nirvāṇa. ${ }^{12)}$

In chapter nine the assembly is at Vimalakirti's place. When the discussions on the bodhisattvas' entry into the doctrine of non-duality (advaya) end, Saariputra worries about their lunch. Vimalakirti reading his mind tells him:

Honorable Śāriputra, the Tathāgata taught the śrāvakas the eight-fold liberation. You should adhere to it and should not listen to the dharma with thoughts related to material things. However, if you want to eat, wait a moment, and you will eat food you have never tasted before. $^{13)}$

The set of texts translated by Zhu Fonian includes: the Antaräbhavasūtra (The Sutra on the Intermediate-State, Zhong yin jing 中陰經), ${ }^{14)}$ the Pusa chutai jing and the Ekottarika-āgama (Zeng yi a han jing 増壹阿含經)! 15)

In the Antaräbhavasūtra the motive appears in a poem of chapter six ("The divine powers", rddhi-pāda 神足) spoken in praise of Subuddhi Tathāgata: 
Among the devas and humans he is the most Honored One without comparison.

His light illuminates the sentient beings.

After having stayed for a long time hungrily and thirsty on the path, they drink by means of the eight-fold release. ${ }^{16)}$

In the Pusa chutai jing the particular combination is found at the end of chapter ten ("Permanence and impermanence" nityā-anity $\bar{a}$ 常無常) in a poem expounded by the Buddha:

Through the eight-fold liberation [I, the Buddha show/produce] the tasty juice of the sweet dharma-dew (甘露法味漿) making those who are thirsty and desirous to feel fully satisfied in an unthinkable way (acintya). ${ }^{17}$

In the Pusa chutai jing and the Antarābhavasütra the metaphor appears in verses or passages that are only loosely linked to narrative contents. Among Zhu Fonian's translations only the Ekottarika-āgama sets the combination into a specific context: Once, the Buddha and his disciples made their begging tour through a certain Brahmin's village, but did not obtain any alms, because Māra had told the villagers not to give anything to the śramamas. At that time the Buddha expounded the wonderful teaching on the nine things or concepts which should be considered as food. One of these is the food of the eight-fold liberation. ${ }^{18)}$

In this light the passages of the Vimalakirtinirdeśa appear as reminiscences of these events. The authors of the Pusa chutai jing and the Antaräbhavasütra were either influenced by the Ekottarika-ägama or by the Vimalakirtinirdeśa. Of some significance might be the fact that while the motive in question is employed for Sugandhakūta in the Vimalakirtinirdeśa and for Subuddhi Tathāgata in the Antarābhavasūtra, the Ekottarika-āgama and the Pusa chutai jing use it for Śākyamuni Buddha.

The Pusa chutai jing points to conservative counter-currents. The discussed motives and events help support its authors' Śākyamuni-centered worldview. Their copying procedures were motivated by their wish to correct passages they thought were diverging from their faith. The Tathāgata's amrta distribution is one out of numerous examples found in the Pusa chutai jing that clearly show an effort to restore the Buddha Śākyamuni's omnipotence. The present paper is only a particular case study. Further important motives and themes, for example from the Lotus 
The Vimalakirtinirdeśa's Narration on the Amrta Distribution and its Exploitation by the Pusa chutai jing's Authors (E. LeGITTIMO)

$s \bar{u} t r a$, underwent similar transformations.

\section{Bibliography}

LAMOTTE, Étienne, L'Enseignement de Vimalakirti (Vimalakirtinirdeśa), 1987, Louvainla-Neuve.

LegitTImo, Elsa I., Analysis of the Pusa chutai jing 菩薩處胎經 (T12, no. 384), International College for Postgraduate Buddhist Studies, PhD thesis, 2006, Tōkyō. (publication planned in the series Mélanges Chinois et Bouddhiques of the Institut Belge des Hautes Études Chinoises, Bruxelles, in 2007)

THE VIMALAKİRTINIRDEŚA, Transliterated Sanskrit Text Collated with Tibetan and Chinese Translations, ed. by the Study Group on Buddhist Sanskrit Literature, The Institute for Comprehensive Studies of Buddhism, Taishō University, Tōkyō, 2004.

1) Cf. Tl2, no. 384 , p. $1015 \mathrm{a} 24$ - 1058b25.

2) On the basis of internal as well as external evidence I showed in my doctoral thesis (cf. LegitTimo, 2006) conducted on this sūtra, that it is not a Chinese composition and was translated around the year $400 \mathrm{AD}$ by Zhu Fonian (筑佛念).

3) Cf. THE VIMALAKİRTINIRDEŚA, 2004, p. 354 - 389. For the Vimalakirtinirdeśa's French translation cf. LAMOTTE, 1987.

4) This power probably bases on the concept of the pureness of the nose (ghrānapariśuddhyā 鼻淨).

5) The passage also refers (with some distinctive deviation) to the first syllables of the ARAPACANA syllabi, cf. Tl2, p. 1022a7 - 1022cl3.

6) Cf. $\mathrm{Tl} 2$, no. 394, p. $1022 \mathrm{c} 8$.

7) One of the thirty-two laksanas of a Buddha.

8) Cf. Tl2, no. 384, p. $1022 \mathrm{c} 24-1023 \mathrm{a} 3$.

9) Cf. Tl2, no. 384 , p. $1032 \mathrm{c} 25-28$.

10) Cf. T14, no. 474, p. 522a, and p. 532a, Tl4, no. 475, p. 450a-b, and p. 552a, and Tl4, no. 476, p. $561 \mathrm{c}-562 \mathrm{a}$, and p. $579 \mathrm{a}$.

11) The three commentaries are the Weimo jing yiji 維摩經義記 (T85, no. 2769, p. 34lc), the Jingming jing jijieguanzhong shu 淨名經集解關中疏 (T85, no. 2777, p. 487b) and the Jinming jing guanzhong shichao 淨名經關中釋抄 (T85, no. 2778, p. 532b).

12) Cf. THE VIMALAKİRTINIRDEŚA, 2004, p. 90 - 91, and Tl4, no. 475, p. $540 \mathrm{b6}$ 10.

13) Cf. THE VIMALAKİRTINIRDEŚA, 2004, p. 354, and Tl4, no. 475, p. 552a5 - 8.

14) Cf. Tl2, no. 385. This sūtra is presently investigated by Prof. Mark BLUM (publication forthcoming).

15) Cf. the Chinese Ekottarika-ägama (T2, no. 125). Although Gautama Samghadeva is 
mentioned as the translator, the greatest part of the collection (or the whole) as we know it today is (still) Zhu Fonian's. Terminological comparative inquiries showed that the Chinese Ekottarika-ägama contains a great number of formulas and expressions exclusively found in works translated by Zhu Fonian. I plan to further investigate this topic in a study dedicated to the Chinese Ekottarika-ägama. On this topic cf. also MIZUNO Kōgen, 1956, p. $41-90$.

16) Cf. Tl2, no. 385 , p. $1065 \mathrm{a} 5-6$.

17) Cf. T12, no. 384 , p. $1032 \mathrm{a} 21-22$.

18) Cf. T2, no. 125, p. 772 b.

〈Key Words〉 初期大乗, 竺佛念, 菩薩處胎経, Vimalakīrtinirdeśa, așta-vimokṣa (Post-doctoral researcher at the International Collage for Postgraduate Studies)

\section{新刊紹介}

Compiled by M. YAMAZAKI and Y. OUSAKA

INDEX TO THE MAJJHIMANIKĀYA

本文 473 頁・定価 35.50 ポンド

Pali Text Society 2006 年 